\title{
TRAJETÓOIA DE UMA ANTROPÓLOGA COM SOTAQUE: ENTREVISTA COM CLAUDIA FONSECA
}

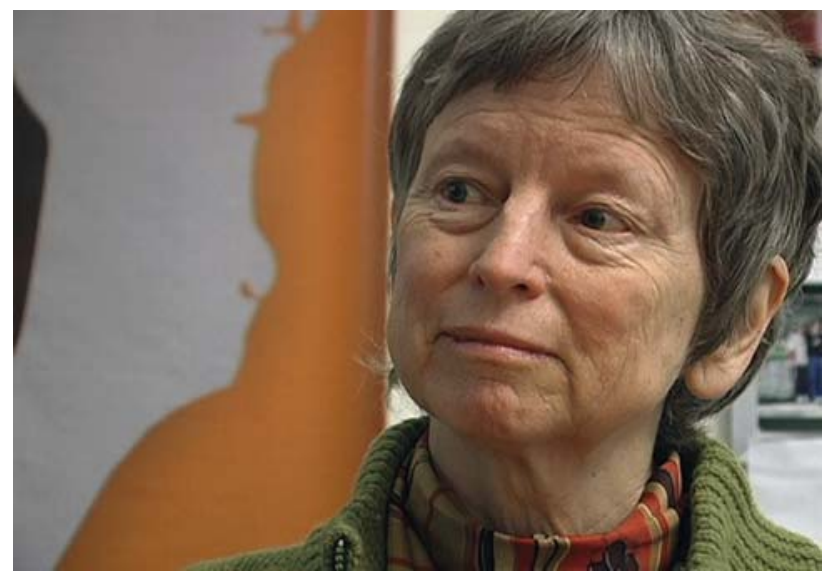

Prólogo

No Departamento de Antropologia e no Programa de Pós-Graduação em Antropologia Social da Universidade Federal do Rio Grande do Sul (PPGASUFRGS), Claudia Fonseca é a nossa "gringa". É com essa identidade sempre pronunciada com carinho que o Prof. Sérgio Alves Teixeira, nosso colega hoje aposentado, costumava apresentá-la aos novatos. Foi também Sérgio o responsável por sua integração ao nosso departamento.

Gringa, sim, pois entre seu prenome e sobrenome tão "brasileiros" consta "Lee Williams" - o que evidencia a sua pertença americana -, e por isso a brincadeira do título - o "sotaque" -, plagiando a expressão de Tereza Caldeira em seus estudos.

Claudia nasceu em Boston, no Estado de Massachusetts. Desde 1978 é professora na UFRGS, onde atuou como professora no Departamento de Antropologia e atualmente é professora permanente no Programa de PósGraduação em Antropologia Social. 
Claudia possui graduação em Letras pela University of Kansas (1967), mestrado em Estudos Orientais pela mesma instituição com dissertação intitulada Taiwan: a developing nation-state - the changing status of women in Taiwan, orientada por Feliz Moos, com título obtido em 1969. Defende seu primeiro doutorado em Sociologia pela École des Hautes Études en Sciences Sociales (1981) quando, sob a orientação de Henri Desroche, apresenta a tese L'adaptation de l'école primaire en milieu rural brésilien: contribution à une anthropologie appliquée dans une étude de cas (Alto do Ribeirão, Minas Gerais). Em 1993 defende seu Doutorado de Estado em Etnologia pela Université de Nanterre com tese intitulada Crime, corps, drame et humour: famille et quotidien dans la culture populaire au Brésil. Realizou dois pósdoutorados, o primeiro pela École des Hautes Études en Sciences Sociales (1990) e o segundo na Université de Montréal (2001).

Claudia tem uma vasta obra produzida nos campos temáticos diversos - como cultura popular, infância, gênero, violência, educação, família, parentesco, direitos humanos, cidadania e ciência. Entre seus livros, os mais citados são Família, fofoca e honra: a etnografia de violência e relações de gênero em grupos populares e Nos caminhos da adoção. No PPGAS-UFRGS organizou, junto com Daisy Barcellos e, posteriormente, com Denise Jardim, o Núcleo de Antropologia e Cidadania (NACi). Orientou inúmeras dissertações e teses e é pesquisadora $\mathrm{CNPq} 1 \mathrm{~A}$.

Claudia é casada com o jornalista brasileiro José Fonseca, e é mãe de Ethon e Pedro, que sempre participaram das atividades de sociabilidade promovidas pelos colegas do Departamento de Antropologia.

Nesta entrevista, com roteiro produzido pelas coordenadoras do Banco de Imagens e Efeitos Visuais (Biev), o propósito foi trazer para um público mais amplo a trajetória dessa antropóloga que já foi coordenadora do PPGASUFRGS, secretária-geral da Associação Brasileira de Antropologia (gestão do presidente Silvio Coelho dos Santos), representante da área de Antropologia na Capes, parte do conselho científico do CNPq e da Fapergs. A entrevista ocorreu no dia 24 de julho de 2008, na sala do NACi, no Instituto de Filosofia e Ciências Humanas da UFRGS, tendo sido gravada pela equipe do Biev.

Convidamos a todos para a leitura desta entrevista em que Claudia relata (como sempre, bem-humorada), uma trajetória de formação em antropologia revestida de impasses, rupturas, ousadias, pioneirismo e projetos internacionais. Esse percurso, iniciado na sua terra natal, revela uma verdadeira "aventura 
antropológica" em que Claudia teve de fazer escolhas temáticas que marcam suas pesquisas no Brasil. Aqui ela não só se enraíza como se torna brasileira, gaúcha e porto-alegrense. Seu simpático sotaque ainda a acompanha e, como ela mesma diz, sempre revela um itinerário internacional, confirmado pelo perfeito domínio de muitas línguas. Lembrando das reflexões de Claude LéviStrauss em Tristes trópicos, a vocação de Claudia é a antropologia.

\section{Aventura}

Cornelia: Em uma conferência recente, disseste que podes definir e contar a tua trajetória acadêmica referindo-te a quatro letras: AAAC.

Claudia: Sim: aventura, alteridade, agency e cidadania. Podemos começar com a aventura, que faz parte desde o início da minha relação com a disciplina. A antropologia sempre esteve ligada à ideia de viajar, de conhecer mundos desconhecidos, de desbravar novos territórios. O antropólogo sempre foi de certa forma um pioneiro. Aliás, eu considerava que o gosto pela viagem era quase um legado familiar. Meu pai era militar da marinha e passei dos cinco aos oito anos morando na Inglaterra, na Alemanha e no Marrocos. O Marrocos foi uma experiência inesquecível. É lá que comecei a estudar francês. Era ainda um protetorado da França. Lembro que a minha mãe, que escrevia contos, narrava a angústia dela de estar vivendo naquela situação colonialista logo antes da independência, com marroquinos sendo perseguidos, morrendo, e ela vivendo naquela bolha da base militar. Meu pai faleceu quando eu tinha oito anos, pondo fim a nossas andanças em lugares exóticos. Mudamos para a Califórnia e depois para o Kansas, onde tive uma adolescência cem por cento americana. Trabalhava aquele "eu" moderno. Lia livros de uma extrema introspecção, como Catcher in the rye. Só na faculdade que lembrei do quanto gostava de viajar.

$\mathrm{Na}$ graduação, sempre com fundos de pesquisa, acabei indo primeiro para a França, depois para a Micronésia, onde tive minha primeira experiência de etnografia (observação participante e diário de campo). Passei dois verões naquelas ilhas, um protetorado das Nações Unidas que tinha sido entregue nas mãos dos Estados Unidos depois da Segunda Guerra Mundial. Palau, que era minha base principal, tinha voos duas vezes por semana vindos da capital 
(Saipan), mas eu estava vivendo num lugar ainda mais isolado - uma ilha periférica a Palau, onde nosso único contato era um barco a diesel que passava duas vezes por semana. Não é nada surpreendente que, quando saturava da "observação participante", me refugiava num baú de livros, completamente orientado para as ânsias de jovens americanos, disponibilizado pelo Peace Corps para a escola primária local. Num primeiro momento, minha orientação teórica e analítica era bastante positivista (e muito pouco reflexiva). Trabalhava dentro de uma vertente que cruzava o difusionismo com o desenvolvimentismo. Na Oceania eu estava estudando a "aculturação" e a "mudança social". Me ensinaram a fazer inventários na venda. Perguntava de onde vinha esse material de consumo, indagava sobre a cultura material, etc. Era até uma maneira de aprender a história, pois encontrávamos camadas de culturas diferentes: a presença do Japão (até o fim da Segunda Guerra Mundial), a influência mais distante da Espanha, da Alemanha e, na época contemporânea, dos americanos. Mas, independentemente da abordagem teórica - hoje completamente superada - fui adquirindo instrumentos de olhar para a realidade, de entrar em diálogo com as pessoas, de registrar os meus sentimentos.

Acho que o diário de campo é um instrumento que tem viajado através das diferentes épocas epistemológicas da própria antropologia. Redigir sistematicamente o diário ia me levando a uma certa perplexidade. À força de ter a experiência de outros lugares, de escrever descrições e depois ler e reler essas descrições, acontece algo na percepção da gente - a sensação de aventura vai cedendo lugar a uma contemplação da alteridade e, com essa diferença, nem sempre acabamos num lugar de herói-aventureiro. É provável que, pelo menos na minha época, poucos estudantes tenham entrado na antropologia com ideias de autorreflexão ou de crítica cultural, mas havia uma experiência geracional que ia nos empurrar nessa direção.

Ana Luiza: Já estavas na faculdade? Em que curso? Tu comentaste antes... em Letras e Matemática, é bem isso?

Claudia: Antes de viajar, eu vivia numa cidade onde tinha uma universidade pública - Lawrence, no Kansas. Entrei na faculdade para estudar Matemática e Letras. Mas, aos poucos, o francês ia ganhando da matemática. O curso de Francês me oferecia bolsas para morar na França e a matemática me parecia cada vez mais distante da realidade. Os matemáticos ficavam 
socados em seus gabinetes para trabalhar com aquelas coisas abstratas. Isso não me atraía.

Tinha tido meu primeiro curso de Antropologia no primeiro ano de faculdade. Foi Antropologia Física, num auditório com cem pessoas. A gente só marcava uma cruz de presença. Olhem as ironias da vida! Era um professor de política conservadora, hoje eu diria de orientação eugênica. Mas ele tinha um carisma que despertava interesse nos alunos pelo estudo da antropologia, "o estudo do homem", aquela antropologia "dos quatro campos" (four-fields anthropology). A gente segue caminhos retos por pistas tortas, não é? Minha segunda disciplina de antropologia foi sobre ossos. O professor fazia consultorias em desastres de avião. Pegava ossos velhos para ver qual era o sexo, a idade de cada pessoa. Sabia recompor o esqueleto a partir de um fragmento... Eu também fui atrás disso, achava muito interessante.

Mas o Departamento de Francês me ganhou com uma bolsa que me permitiria passar meu segundo ano de faculdade na Université de Bordeaux, na França. Tinha 17 anos. Naquela época, ainda acreditava que ia seguir adiante com Letras. Mas na França fiz minha primeira cadeira de Sociologia com um grande professor bem conhecido na área dos estudos sociais da ciência e tecnologia, Jacques Ellul. Ele recém tinha lançado L'enjeu du siècle - um livro sobre a lógica da tecnologia - e eu me apaixonei por aquela matéria. Era uma aula absolutamente magistral. Não perdia uma frase, do início até o fim. Hoje reconheço que era puro determinismo tecnológico, mas na época para mim era novidade. Era como um Foucault avant la lettre. Mostrava como a tecnologia trazia embutidas determinadas maneiras de pensar. Assim, mais uma vez eu estava me aproximando da área das ciências sociais.

Durante a minha formação na França, levei adiante minhas explorações existenciais. Lia muito naquela época. Teatro francês do século XX, eu adorava. Um pouco de poesia. Tive uma formação sistemática na literatura francesa. Mas também estava lendo literatura contemporânea dos Estados Unidos: lembro de James Baldwin, Malcolm X, Steinbeck, Faulkner - que eram as coisas daquela época nos Estados Unidos, da chamada Revolução Social. Quando voltei da França, não era mais a mesma pessoa nem em termos intelectuais nem em termos políticos. Segui adiante com cadeiras de Antropologia, descobrindo novas facetas da disciplina. O especialista na etnologia do Extremo Oriente costumava passar filmes nas aulas e fui me apaixonando pela matéria através da área visual. Agora, até o estudo da poesia francesa começou a 
parecer algo "distante da realidade", e assim meu curso de Letras foi ficando em segundo plano. Quando veio o convite de ir para Taiwan (Formosa, naquela época, ou "China Nacionalista"), não pensei duas vezes.

Ana Luiza: Importante essa ênfase que dás à tua experiência inicial. $\mathrm{Tu}$ comentas sobre essa passagem no Marrocos e passas mais tarde por uma experiência na China. Interessante essa tua relação com o Ocidente e com o Oriente... e falas sobre um certo Oriente e um certo Ocidente. Isso implica um aprendizado todo singular sobre o tema do poder que está presente na tua obra, sobretudo nos últimos anos, quando abraças o tema dos direitos humanos, tratas da questão dos direitos sociais... a questão da infância... ou seja, coisas que a gente vem vendo ao longo do caminho. Como relatas esse deslocamento, entre sair um pouco dessa cultura material para entrar em outro plano, com outro tipo de hierarquia e valores? Não são só diferenças entre ocidentais e orientais, mas no âmbito dessas culturas, suas microdiferenças, seus problemas. Começas a descobrir uma riqueza no interior da própria diferença, a riqueza da alteridade. Eis nossa provocação.

Claudia: Sim. Eu diria que embarquei nas minhas primeiras experiências etnográficas de forma absolutamente ingênua. Tal como muitos de nossos estudantes, também trouxe para o ofício meus desejos humanitários: queria salvar o mundo. Sou da geração dos anos 1960, nos Estados Unidos. Marchei na rua contra a guerra do Vietnã, participei de movimentos antirracistas, etc. Mas tinha um diferencial na minha experiência pessoal: eu tinha vivido parte de minha infância no exterior, eu tinha conhecido outros países. Minhas experiências no exterior operaram um tipo de desconstrução do que vivia nos Estados Unidos - aquela adolescência idílica.

Comecei a estudar o Extremo Oriente no meu terceiro e último ano de bacharelado porque achava digna de nota a experiência comunista na China. Comecei a estudar chinês e me ofereceram uma passagem aérea para passar sete meses em Taiwan. Era o único território da China aberto a americanos nessa época. Essa ilha, conhecida como a "China Nacionalista", tinha sido ocupada por Chiang Kai-shek e seus aliados políticos quando eles fugiram do continente, expulsos por Mao Tse-tung. Conforme a narrativa hegemônica nos Estados Unidos, os nacionalistas eram os defensores da liberdade democrática (os comunistas "comiam crianças"). Mas, uma vez chegada na ilha, falando 
com as pessoas, comecei a ver uma série de "furos" nessa história. Quando Chiang Kai-shek e "sua turma" chegaram do continente, marginalizaram as pessoas da ilha. Implantaram um governo, apresentado como verdadeiro representante da China, que concedia aos "locais" uma mínima participação

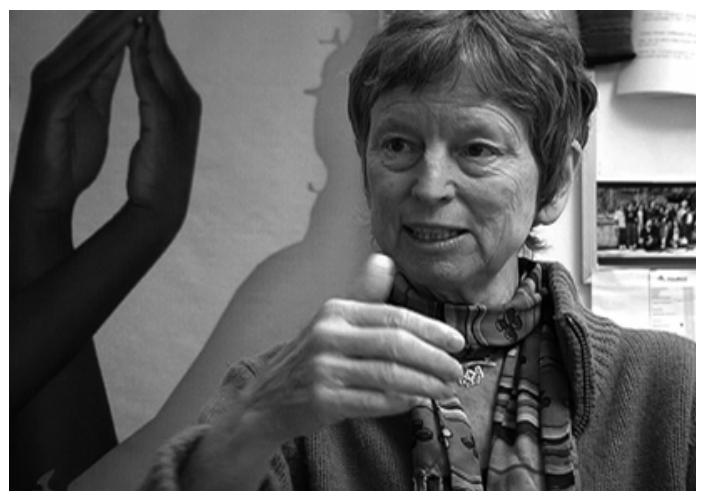
nos órgãos desse governo.

As pessoas (de origem chinesa) que moravam na ilha há gerações passaram a ser vistas como rustres, "atrasadas" - ideias que legitimavam a dominação pelos "continentais". Foi nessa época que comecei a me interessar seriamente pela questão da desigualdade política e tive meu primeiro namoro com a antropologia política e a problematização da própria noção de Estado-Nação. Hoje, posso ver que eu fazia parte de certa esquerda intelectual que tinha um idealismo cego em relação à China comunista. A Revolução Cultural começou logo nessa época e foi uma época terrivelmente violenta. Mas minha atenção estava voltada para a injustiça perpetrada pelos nacionalistas, supostamente democratas, contra seus próprios súditos em Taiwan. É interessante, quando a gente olha para trás e vê como cada experiência etnográfica ilumina certas coisas e deixa outras no escuro. É com o tempo, com a história, com a memória, que a gente vai retrabalhando essas prioridades.

\section{Alteridade}

Ana Luiza: Que idade tinhas nessa época?

Claudia: Tinha 19 anos quando fui a Taiwan. Terminei minha tese de mestrado em Estudos Orientais dois anos mais tarde - uma reflexão sobre Taiwan enquanto Estado-Nação em formação. Até lá, já tinha trabalhado como assistente de pesquisa na Micronésia. Em cada situação fui "apanhando", me sentindo a própria gringa colonialista. Em Taiwan, era porque todo 
mundo procurava uma maneira para sair da ilha - tanto os nacionalistas (recém-chegados do continente) quanto os taiwaneses radicados há gerações na ilha. Por isso, queriam fazer amizade comigo, aprender inglês, e assim chegar aos Estados Unidos. Irritava-me profundamente essa adulação aos Estados Unidos, mas eu tinha que "baixar a bola" e me dar conta de que a lógica das pessoas era perfeitamente coerente com a situação política e histórica em que viviam. Era eu que não levava em consideração essa situação. Assim, comecei a refletir sobre quais as circunstâncias históricas que produzem uma relação interpessoal dessa natureza tão radical, tão violenta.

Minha experiência na ilha de Palau também me ensinou algo sobre a alteridade. A experiência foi muito diferente da de Taiwan, onde a língua tinha representado sempre o maior desafio em termos de comunicação. $\mathrm{Na}$ Micronésia as pessoas falavam inglês, iam para a escola onde o ensino era em inglês, e havia uma elite, uma jovem elite formada sob a influência americana desde o fim da Segunda Guerra Mundial. Era uma situação interessante. Tinha tensões de gênero, porque eu era uma menina branca... A primeira vez, acho que tinha 18 anos. Cheguei lá com toda a infraestrutura da universidade nos Estados Unidos: carro alugado, salário e tal. E na interação com os jovens locais comecei a aprender que eu era uma "agente do imperialismo yankee". Era só indo para o interior que eu escapava dessas acusações. Então me agradou ir para o "interior do interior", porque me sentia mais confortável, porque lá não estava tão confrontada a uma situação que me obrigava a repensar o meu lugar nesse modelo.

Ana Luiza: E como se transcorreu nesse processo a reflexão sobre o papel da etnografia e do antropólogo? É o início da reflexão crítica da própria disciplina. Como vives essa experiência?

Claudia: A crítica cultural começa nos anos 1970, mas se consolida na década de 1980. E eu estou falando do fim dos anos 1960. Creio que é um legado das insatisfações da minha geração, que "deu" nessa virada política. Os antropólogos norte-americanos até esse momento sempre queriam estudar o exótico. Só depois de reconhecer o agency desses "outros" (apanhando deles) que se volta para a ideia da crítica cultural. Nessa época, minha própria resposta à situação foi a de abandonar de vez a vida acadêmica. Eu tinha começado o doutorado na Columbia University (New York). Era 1969 e o mundo 
estava vibrando com as sequelas de Maio de 68. As coisas estavam explodindo em toda parte e me parecia que meus professores estavam completamente alienados dos tumultos da "vida real". Certamente, na minha juventude, não tive paciência para parar, escutar e dialogar para entender a forma de engajamento deles. Mas havia outras coisas que me inquietavam. "Caiu a ficha" de que minhas idas à Micronésia tinham sido financiadas pelo Departamento de Defesa dos Estados Unidos. As autoridades americanas tinham todo o interesse em conhecer melhor essas ilhas no Pacífico, caso tivessem que recuar do Vietnã e encontrar bases militares em outros territórios. Minhas bolsas de pós-graduação, muito generosas, vinham sempre da National Defense Foreign Language Act, e eu já estava recebendo propostas de emprego de organizações governamentais tais como a National Security Agency (NSA). No meio de tudo isso, li um artigo de Kathleen Gough - uma grande e respeitada antropóloga - em The New Left Review, em 1968. O título diz tudo: "Anthropology, child of imperialism". Comecei a ter a sensação de que estava sendo preparada para ser aliada do "complexo militar-industrial" contra o qual nós estudantes lutávamos. Em suma, mal completei meu primeiro semestre, pois não ia mais seguir adiante na carreira acadêmica. Larguei meus contatos, meu chinês, as experiências de campo - tudo.

Sem dúvida meu namorado brasileiro também contribuiu para minha decisão. Ele tinha sido militante estudantil em Belo Horizonte - onde estudava jornalismo - e sua família o tinha convencido, tão logo se formou, a sair do país para fazer um mestrado nos Estados Unidos. Mas ele estava abatido, olhando dessa distância para toda a violência do golpe. Queria voltar. Assim, no início de 1970, fomos os dois para o Brasil, onde ganharíamos a vida durante seis meses dando aula de línguas. Foi um banho de água fria, uma lição. Depois de alguns meses com a família de José em Minas Gerais (uma visita relativamente tranquila), fomos para São Paulo, onde tinha um guarda com metralhadora em cada esquina. Não entramos em nenhum movimento, mas José visitava seus amigos na cadeia, mantinha redes de solidariedade com aqueles que estavam vivos. Tinha suicídios também, não eram somente pessoas mortas diretamente pela ditadura. A pressão era muito grande e alguns não aguentaram a experiência da cadeia. A gente foi sentindo que nesse clima havia só duas opções. Ou entrar na luta, com todas as consequências, ou não ficar mais lá. Então, depois de seis meses em São Paulo, fomos embora para a França. 
Ana Luiza: Como foi a experiência na França?

Claudia: Foi, quase apesar de mim, um retorno para a antropologia. Entre todos os outros bicos que fazia para sobreviver (como babá, garçonete e tradutora), tinha conseguido um emprego na Unesco. Entrei como estagiária, arquivando documentos. Lá, tomando café nos intervalos, conheci alguém que procurava um especialista em antropologia para assessorar um programa de alfabetização funcional para mulheres na África ocidental. Eu tinha mestrado em Estudos Orientais e um pouco de experiência etnográfica. Não acharam outro candidato mais adequado. Assim, em 1971 fui para África. Nunca fui tão bem paga.

\section{Ana Luiza: Um mergulho na África, Claudia?}

Claudia: No Alto Volta, que hoje é Burkina Faso. José e eu ficamos nove meses entre os kassena em Pau, um município de cerca de 5 mil habitantes a 18 quilômetros ao norte da fronteira com Gana. Ainda tinha esperança de contribuir para o "desenvolvimento do Terceiro Mundo" - esperança que, mais uma vez, foi se desmistificando. Mas isso é outra história - que saiu na revista Anthropos (Fonseca, 1982), na minha primeira publicação acadêmica. Não vou me alongar aqui.

Ana Luiza: É interessante que trazes para a reconstrução da tua trajetória as questões do campo em que carregamos as marcas da nação, da língua, de gênero, de classe.

Claudia: Eu comecei meu campo com aquela ideia de que "somos todos seres humanos iguais". Assim, podia acontecer uma grande comunhão de personalidades. Pensava: "Eu não sou colonialista, não compactuo, não me identifico com aquelas pessoas. Eu não tenho cor, não tenho sexo, não tenho nacionalidade, não tenho classe..." [risadas]. Ledo engano. Essas são coisas que a gente não pode ignorar.

$\mathrm{Na}$ África, conheci pessoas absolutamente maravilhosas durante esse período - muitas das quais nunca tinham visto um branco antes, e nessas situações era muito mais fácil travar o que eu achava ser uma relação "autêntica". 
Não sabiam como me classificar, entendeu? Então me aceitavam quase como curiosidade. Lembro da primeira vez em que passamos o dia numa pequena aldeia afastada de tudo. O chefe da aldeia veio para me olhar comer o almoço que tinham preparado para nós (da planta de sorgo com um molho verde). Deu uma risada de quase alívio e disse: "Ela come pela mesma boca que nós." (Na verdade, já que eu não falava kassena, tudo passava pelo intérprete, mas desconfio de que havia ainda uma segunda parte nessa observação...). Nessa mesma aldeia, que vim a conhecer bastante bem, tinha um ancião que sempre me saudava - e me apresentava aos outros - como sua "amante". Sempre me diziam, aliás, que não conseguiam calcular minha idade porque eu escondia meus peitos debaixo de uma camisa. Foi com os kassena que fui apreciando as pitadas de ironia e humor que faziam parte da "observação nativa" de nós.

Onde eu encontrava problemas de comunicação era com as camadas médias escolarizadas que já estavam trabalhando, em grande medida, dentro de registros semelhantes aos meus - o que tornava "nós" e "eles" competidores dentro de um campo de recursos (simbólicos e materiais) limitados. Nunca vou esquecer uma situação que passei em Pau. Tínhamos uma amiga de visita na cabana da gente - uma jovem americana negra que estava viajando pela África meio incógnita, vestida de africana. Aquela noite soubemos de um funeral e resolvemos ir (porque os funerais são extraordinários, com música, dança - uma grande festa a céu aberto). Fomos nós quatro - meu marido e eu, a nossa visita e a mulher que vivia na cabana encostada à nossa. Na festa funerária, as pessoas se colocam em roda - de onde podem se lançar facilmente para participar da dança - e os velhos venerados ficam sentados numa poltrona, para observar os dançarinos. O problema era que o falecido era de uma família que tinha um funcionário público, com ensino superior - acho que era sociólogo - que tinha vindo da capital, Ouagadougou, para assistir ao funeral de seu avô. E ele mesmo estava sentado numa dessas poltronas, ao lado dos anciões. É interessante porque, na época, a situação de classes não era igual ao que conhecemos no Brasil. Na África tu encontravas funcionários com doutorado na França, altamente sofisticados, cosmopolitas, mas esses funcionários podiam ter um irmão analfabeto ou um sobrinho vivendo da agricultura de subsistência que nunca tinha saído da aldeia. Podia ter enormes diferenças dentro de uma mesma fátria. 
Voltando ao funeral... Tínhamos ido como espectadores, figurantes secundários, porque não tem como ficar em casa escutando os tambores sem dar vontade de ir para a festa. Pensávamos que ninguém ia nos dar bola, pois, apesar de brancos, éramos jovens e ainda acompanhados de pessoas do local. A certa altura, esse jovem funcionário público (tinha 20 e poucos anos, que nem a gente) levantou e veio nos dizer, para mim e meu marido: "Vocês, venham sentar..." Tinha só três poltronas - a ideia era tirar os anciões das poltronas esses velhos venerados da família - para nos deixar ocupar o lugar. Inclusive, o "cara" tinha completamente ignorado as duas moças (negras) que tinham vindo junto conosco "curtir" a festa. Ou seja, na nossa leitura, estava nos convidando a compactuar com um tipo de simbolismo colonialista que nós abominávamos. José e eu tentamos dizer "não, muito obrigado, a gente não vai ficar por muito tempo, não precisa, etc., etc.", mas o "cara" ficou muito agressivo. Dizia: "Eu sei que jogo vocês estão jogando. 'Tão' aqui bancando nativos, mas na verdade..." Não lembro todos os argumentos, mas com a independência nacional ocorrida há menos de dez anos, ele estava exibindo cicatrizes abertas. Em todo caso, acabou nos expulsando da festa. O "cara" veio no dia seguinte, nós debatemos uma tarde inteira, mas saí da conversa ainda mais perplexa. Se acontecesse hoje com um estudante meu, eu diria: "Faça diário de campo" - é justamente esse tipo de situação que nos ajuda a entender mais sobre essa tal de "alteridade". Mas a antropologia ainda estava longe da era da autorreflexão... e não me dei conta, na hora, do quão importante era aquele episódio doloroso.

Tive experiências análogas na Micronésia, em Taiwan e mesmo no interior de Minas Gerais. São experiências que te obrigam a pensar teu lugar dentro do campo. Comecei querendo que as pessoas aceitassem aquele "eu" singular que tinha cultivado durante tantos anos. Acabei vendo que, na interação com os outros, eu ocupo um lugar, possuo um corpo, uma cor de pele, uma classe. Tudo isso vai mediando a percepção do sujeito - a minha deles e a deles de mim. Ainda por cima, em tantas situações, o antropólogo está gozando de vantagens estruturais: está recebendo um salário, é respaldado por autoridades locais, etc. Assim, ao lado de todo o resto, tu carregas o histórico da disciplina, e tu tens que assumir e negociar isso. Apesar de todas as tuas boas intenções, tu não podes te dissociar daquele contexto e não podes ficar completamente surpreso quando confrontado com as incoerências e contradições da situação. 
Na Micronésia e na África tinha pessoas que me confrontavam. Quando cheguei nas vilas de Porto Alegre, foi diferente. Na África, na China e na Micronésia, sabiam só olhando para mim que eu era de fora. Mas na vila não necessariamente! Havia situações quando a pessoa chegava dizendo: "Ah, eu te conheço. Tu és tia do Paulinho, né?!" Ai, eu adorava! Mas bastava abrir a boca que assumia outro lugar nessa configuração.

Cheguei na vila através da indicação das crianças que passavam na minha porta todo dia pedindo restos de comida. Perguntei para elas "onde vocês moram?" e fui atrás do local. Mas eu não comecei na casa das crianças. Comecei batendo nas portas, assim como uma idiota, sozinha: "Tô aqui fazendo uma pesquisa para a universidade sobre tal e tal coisa, quer falar comigo?" Acho que em muitos casos as pessoas nem entendiam direito o que eu estava falando, porque o meu português era ruim, mas as portas se abriam. Por incrível que pareça, sabe? Uma sociedade hierarquizada, quase estamental, com discriminação de raça e classe violenta, e eu fui recebida quase sempre de forma muito cordial. A gente tem que perguntar: "Por quê? Por que tem tremenda tensão em uma situação e tão pouca em outra?" Tanto que tu consegues levar adiante a tua pesquisa com a ilusão de que todo mundo entende todo mundo, todo mundo ama todo mundo, que nós somos uma grande comunidade. O que significa esse ambiente tão afável? É indicação de uma sociabilidade popular? Ou de uma relação que as pessoas morando em vilas têm com certa categoria de "burguês", uma "patroa" em potencial? Era prova de uma espécie de "colonialismo interno" ou de ainda outra coisa?

\section{Agency}

Ana Luiza: Mas a sociedade também se desloca no tempo, hoje talvez uma pesquisa como a que fazias não ocorra da mesma forma. Hoje com o Estatuto da Criança, etc., temos mais paranoias, somos mais temerosos de nossas ações no grupo, não achas? E com isso provavelmente a forma de produção da etnografia foi se transformando. Gostaria que comentasses como esse processo se dá para ti no Brasil. Na tua obra abordas essa questão da sociedade brasileira e suas hierarquias, a relação da violência, da condição de vida de crianças em classe popular, da mulher, da relação homem e mulher e gênero? 
Claudia: Talvez eu não apanhasse tanto dos meus "nativos" no início porque os elementos hierárquicos estavam mais sedimentados. Certamente, com a reabertura democrática, o orçamento participativo, a universalização efetiva do ensino, essa situação tenha mudado ao longo dos últimos 30 anos. Hoje é muito difícil chegar num campo sem passar pelas autoridades locais (quer sejam políticas, religiosas ou do tráfico...). Por outro lado, nossos "nativos" no morro agem mais como parceiros ou interlocutores do que como objetos de pesquisa. Não somente são críticos, mas também, muitas vezes, procuram influenciar na própria pauta de pesquisa. Eu que sempre me esquivava das "autoridades", querendo evitar mediações institucionais, agora trabalho o tempo todo com e através dos conselhos tutelares, das escolas, da Comissão dos Direitos da Criança... e uma série de ONGs. De simples "alteridade", é como se a ênfase de nossas pesquisas sobre "o Outro" tivesse evoluído para algo mais dinâmico, mais dialógico. A própria noção de agency traduz algo desse clima. Em todo caso, a nossa relação com os "informantes" [gesto de aspas com as mãos] não pode ser mais uma relação inocente. Hoje, os estudantes, desde a sua formação, já trazem o conhecimento desses confrontos, dos paradoxos inerentes à relação sujeito-objeto.

A gente não pode nunca esquecer o papel dos estudantes. Trinta anos atrás, me lembro bem, enfrentava na sala de aula provocações constantes tanto intelectuais quanto políticas. Os estudantes estavam inquietos! Dar aula é como uma pesquisa de campo. Se você presta atenção ao que os alunos estão dizendo, às críticas, às chatices, às expectativas frustradas e realizadas, é um caminho para entrar num outro tipo de "alteridade". Para mim foi um contato ainda mais importante, porque eu era "gringa" (brincavam que eu podia ser agente da CIA), e eu dependia dos melhores estudantes da graduação (pessoas como Miriam Grossi e Carmen Rial) para me introduzirem aos "costumes locais". É irônico: se nossos "nativos" no morro são hoje muito mais assumidos nas suas reivindicações e críticas à pesquisa antropológica, parece que os estudantes são bem mais comportados. Claro, há fatores "externos" que mudaram minha relação com os estudantes: sou hoje uma anciã grisalha, com certo peso institucional - o que obviamente não era o caso nos anos 1980. Mas também o contexto atual é outro. A gente nunca sabe se a realidade tem mudado ou se sou eu que mudei, ou... sabe? Ou se são os elos intermediários que te obrigaram a mudar teu olhar, tua perspectiva. 
Cornelia: És pioneira no trabalho antropológico aqui sobre o tema da questão infantil e de gênero. Depois introduziste no programa [PPGAS] a linha de pesquisa dos direitos humanos e cidadania. Não queres falar um pouco do Núcleo de Antropologia e Cidadania?

Claudia: Bem, acho que já descrevi um pouco do início desse meu envolvimento. Para mim foi extremamente incômoda a sensação de vir de uma situação privilegiada - das classes dominantes, do americano, do anglófono, do trabalho na Unesco... E eu? O que eu vou fazer com isso? Num primeiro momento, tinha a reação de querer espalhar esses privilégios, de "ajudar". Aí aprendi com cada nova experiência - na Micronésia, em Taiwan, no Alto Volta - que não estava ajudando ninguém. Estava fincando "o prego do imperialismo" mais fundo no coração dos explorados.

Nesse sentido, foi fundamental quando eu cheguei ao Brasil e assumi como professora universitária. Eu tinha essas preocupações políticas que não estavam totalmente no ambiente da época. Era um momento de intensa discussão, Diretas Já, a redemocratização, etc. Desfrutei do espaço que me foi oferecido aqui na UFRGS muito generosamente pelos colegas Ruben, Sérgio, Noemi, Daisy e pelos arqueólogos que eram padre Schmitz, Rambo e Brochado. Fui aprendendo e amadurecendo e tendo uma atitude mais profissional. Fui vendo que não adianta ficar te torturando com atitudes de culpa, o não dá uma boa consequência nem política nem acadêmica. Ainda defendi meu primeiro doutorado na EHESS à base de uma pesquisa sobre "educação popular" (à la Paulo Freire) para uma comunidade mineira de trabalhadores agrícolas, mas depois disso eu decidi: "Quero me afastar de qualquer coisa aplicada... Se conseguir entender algo do que as pessoas pensam, sentem e fazem, e de como minha pesquisa vai afetar tudo isso, já está bom."

Para meu Doutorado de Estado, agora na Universidade de Paris X (Nanterre), acabei travando contato com Colette Pétonnet (CNRS e Université de Nanterre) - uma pioneira da antropologia urbana na França. Sua maneira de investigar a vida do "subproletariado" da periferia parisiense, junto com sua enorme sensibilidade etnográfica, fizeram dela uma orientadora perfeita. Foi uma interlocução muito rica e que incluía outras figuras da vida acadêmica francesa - em particular, Françoise Zonabend, especialista no Collège de France da etnologia francesa. Eu sempre digo, entretanto, que a minha verdadeira formação acadêmica e intelectual se dá aqui no Brasil. A minha vocação de antropóloga 
desbravando lugares novos se deu antes, tudo bem. Mas a minha maneira de viver com essas atividades, de combinar o construtivo com o crítico a longo prazo ocorreu aqui em interlocução com a comunidade científica brasileira.

Cornelia: Um momento importante de tua produção etnográfica, não, Claudia?

Claudia: Talvez o período mais intenso tenha sido durante a pesquisa de campo sobre cultura popular em vilas de Porto Alegre. Subi o morro em companhia de outros pesquisadores. Robert Shirley, especialista em antropologia do direito, estava como professor visitante na UFRGS nessa época e estava querendo investigar as formas costumeiras para a resolução de conflitos. Também comecei a ter estudantes ajudando: Jurema Brites foi minha primeira bolsista IC, Claudia Magni estava iniciando seu longo envolvimento com moradores de rua e Miriam Chagas estava "se achando" entre os pedintes/ participantes do estúdio de uma rádio popular. Na minha maneira de ver, duas coisas fundamentais saíram dessas pesquisas. Em primeiro lugar a etnografia oferecia maneiras alternativas - menos moralistas - para pensar práticas em grupos populares. No meu próprio trabalho insistia muito na noção de "circulação de crianças" para combater estereótipos simplistas sobre a desagregação familiar (ver Fonseca, 1995). Foi uma linha de investigação que deu muitos frutos. A outra coisa que eu achava importante nesse material dizia respeito a uma questão estética e metodológica - a maneira como ironia e humor faziam parte integrante do estilo de vida, da expressão de valores (Fonseca, 2000). Era uma reflexão metodológica, mais dirigida à comunidade de pesquisadores. Na época, eu e alguns dos meus estudantes (por exemplo, Motta, 1998; Boff, 1998; Fonseca, 1991) estávamos fascinados por Bakhtin e os historiadores "das sensibilidades" que nos levavam para esse caminho.

As demandas que passei a receber para assessoria em ONGs e órgãos de governo que lidavam com questões de gênero, família e crianças se remetiam invariavelmente ao primeiro ponto. Minhas inquietações se comunicaram para um público maior, em grande medida graças a Ciranda, cirandinha (1994) - vídeo que tinha sido concebido e realizado por estudantes da graduação. Assim, depois de ter feito uma pausa de quase dez anos, me encontrei mais uma vez enredada em projetos de "intervenção". Em outras palavras, depois de defender o segundo doutorado, no início dos anos 1990, não escapei do clima de mobilização política. A poucos anos da nova Constituição brasileira, 
numa era de grande proliferação de ONGs e outros serviços em nome da “justiça social", vim mais uma vez a modificar a maneira como eu estava vivendo minha atuação profissional...

\section{Cidadania}

Ana Luiza: E a relação do NACi também, eu imagino, na relação com essas políticas de Estado, não, Claudia? Eu acho que aí entra o trabalho do NACi e das pessoas que vêm também para ter orientação, entendes? Os trabalhos que são feitos também contribuem para um retorno a esse processo das instituições democráticas no Brasil. Isso é uma coisa que mudou bastante.

Claudia: Sim, iniciamos o NACi - acho que foi em 1995 - com uma pequena verba do CNPq. Tem sido um espaço, como todos os nossos núcleos, de uma retroalimentação muito rica. Dentro da política institucional, não é sempre fácil achar exatamente o lugar onde nós nos sentimos intelectual e politicamente confortáveis. A política acadêmica não exige, necessariamente, esse envolvimento: exige que publiquemos, que façamos parte de uma comunidade internacional de grandes "crânios", etc. Mas a criação de um espaço de interlocução dentro da universidade se deve muito aos alunos.

No início, eram especialmente os alunos da graduação que traziam suas ânsias políticas para a disciplina. Sempre ciosa das "boas intenções que saíam pela culatra" (Fonseca; Cardarello, 1999), resisti. Mas a certa altura pensei: "Bueno, eu vou ser que nem os professores da Columbia University, dos quais eu fugi? Que diziam para os alunos: 'Não queremos saber nada de coisas aplicadas. Você está aqui para aprender a se distanciar dos fenômenos sociais e a publicar artigos em revistas acadêmicas. Pronto." Não eram somente os alunos, mas também o departamento e todo um clima da antropologia brasileira - que Mariza Peirano (1992) descreve tão bem. Começávamos a problematizar o fato de fazer "antropologia em casa" - quando o estudioso é cidadão do lugar, da realidade que está pesquisando. Diferentemente da antropologia clássica, é muito difícil, depois de acabar a pesquisa, simplesmente "virar a página" e esquecer os sujeitos com os quais tivemos tanta intimidade durante os anos de campo. Estávamos começando a pensar: "Eu sou pesquisadora, eu sou antropóloga, mas também sou cidadã desse país. E qual é o meu lugar dentro de tudo isso?" 
Passei a receber convites para fazer pesquisas nas diferentes instâncias de intervenção e ia junto com os estudantes. Alinne Bonetti, por exemplo, que tinha começado com o NEP (Núcleo de Estudos da Prostituição), continuou suas pesquisas com a ONG feminista Themis (Assessoria Jurídica e Estudos de Gênero). Elisiane Pasini ficou aprofundando a questão da prostituição. Andrea Cardarello estava fazendo campo na Febem, Fernanda Ribeiro com os conselhos tutelares, e Heloisa Paim estava com a Fasc - órgão municipal de amparo. Assumíamos agora que, entre nossos objetivos, constava o de "contribuir" para a qualidade de vida dos sujeitos enquadrados por essas instituições. Era um programa que levaria os estudantes a aprender antropologia "com a mão na massa" e não simplesmente através de textos.

A certa altura, o NACi passou a atrair novos estudantes de pós-graduação. Marta Jardim, que trabalhava na Febem, Simone dos Santos, que era da Fasc, Patrice Schuch, que já trabalhava como socióloga concursada na Febem. Entre os mestrandos, mesmo quando o estudante não era funcionário de uma instituição de intervenção, escolhia objetos que provocavam reflexão sobre nossos esforços "civilizadores". Penso, por exemplo, em Antonadia Borges entre os assentados do Paraná, Diego Soares com o MST no Rio Grande do Sul. Muitos desses esforços saíram publicados não somente em teses, mas também em coletâneas tais como Etnografias da participação (Brites; Fonseca, 2006) e Políticas de proteção à infância (Fonseca; Schuch, 2009). Fora um ou dois que ainda estão se doutorando, todos esses estudantes são hoje professores universitários...

Até o final dos anos 1990, eu estava cada vez mais envolvida no campo da antropologia do direito. Era um ponto de convergência tanto de minhas inquietações teórico-analíticas quanto das demandas de assessoria dirigida a metas envolvendo cidadania, direitos humanos, justiça social. Nessa época, o NACi contava com duas outras grandes pesquisadoras. Daisy Barcellos, cofundadora do núcleo, era especialista em relações interétnicas. Estava inspirando toda uma geração de estudantes a pensar minorias étnicas, direitos constitucionais, quilombolas. Pegavam assessorias junto aos órgãos públicos que resultavam em estudos monumentais (Barcellos et al., 2004). Denise Jardim, com sua experiência entre as famílias palestinas na fronteira entre Brasil e Uruguai, também atraía estudantes que, com estudos sobre migração e nacionalidade, focavam na questão da lei, da administração da justiça, questões de governança (ver Jardim, 2007). O NACi juntava todas essas equipes numa interlocução riquíssima, e, em 2004, Denise, juntamente com as doutorandas Cintia Müller e Patrice Schuch, resolveu colocar uma "cara institucional" em 
toda essa atividade, através do Projeto Pronex CNPqFapergs "Práticas de Justiça", sob minha coordenação. A essas alturas, já estávamos organizando cursos de extensão e outras atividades extracurriculares. O auxílio Pronex, junto com a incrível energia de Denise - que estava cocoordenando

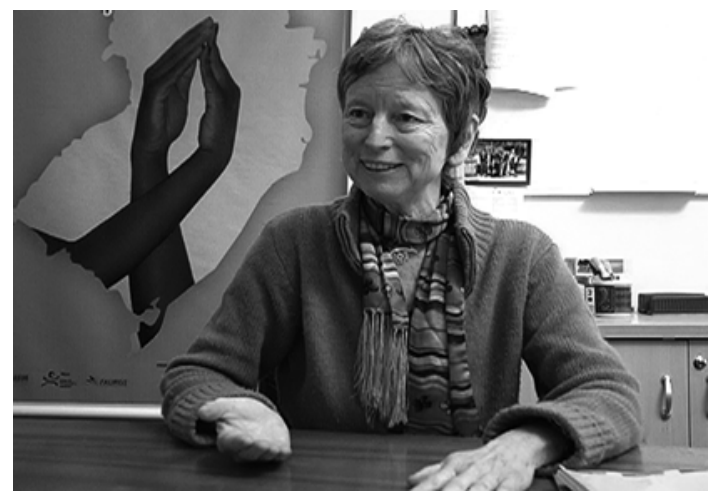
o NACi -, permitiu levar adiante esse impulso inicial para mais cursos de extensão, jornadas periódicas de antropologia e direitos humanos na UFRGS e no interior do estado (Ijuí, Pelotas, Santa Maria...), além de um grande número de teses e dissertações. Graças ao projeto, instaurou-se uma disciplina na graduação sobre antropologia e direitos humanos. Sob a firme orientação das doutorandas do NACi, Soraya Fleischer e Patrice Schuch, os estudantes de duas dessas turmas tiveram sua primeira experiência de colaborar numa publicação coletiva, sublinhando as ansiedades de sua geração quanto ao exercício de uma antropologia aplicada (Fleischer; Schuch; Fonseca, 2007).

Eu diria que essa interlocução no NACi, entre a universidade e as instâncias de intervenção (ONGs, movimentos sociais, governo), nunca ficou fixa em um ponto confortável. Nesse diálogo entre uma antropologia teórica e nosso envolvimento enquanto cidadãos, parece que o teórico desafiava o político e vice-versa. Assim, classe, raça, gênero, nacionalidade - todas essas intersecções nos obrigavam a agilizar nossos conceitos, a evoluir... Quanto ao resto, não seria prudente exagerar o impacto político de nossa contribuição. Não convém ter grandes ilusões... mas a gente vai vivendo cada novo desafio, "apanhando" com cada nova experiência, e costurando essas diferentes passagens com otimismo, com espírito crítico dentro da nossa definição de uma atuação possível.

Cornelia: Antes de encerrarmos, teus projetos atuais.

Claudia: No ano 2000, desfrutei de uma bolsa pós-doutorado na Université de Montréal. Comecei uma nova interlocução no cenário internacional com 
antropólogas especializadas na circulação de crianças - Chantal Collard, Françoise-Romaine Ouellette, Barbara Yngvesson, Anne Cadoret, Diana Marre... Engraçado - lá fora sou considerada antropóloga quase cem por cento brasileira. Quer dizer... em português eu tenho esse sotaque de gringa, mas eles não sabem disso [risadas]. E eu acho que a minha maneira de pensar, as minhas contribuições refletem a riqueza da antropologia brasileira.

Hoje tenho um fascínio pela antropologia da ciência. Em artigos mais recentes, tentei mostrar como esse interesse representa a culminação mais ou menos lógica de minha passagem pelas áreas temáticas de gênero e parentesco (Fonseca, 2003, 2007). O universo empírico dos solicitantes de um teste de paternidade DNA (localizados nas varas de família, na defensoria pública, etc.) acabou se mostrando um ponto perfeito de convergência entre meus interesses pela antropologia legal - família, parentesco, gênero, filiação, novas tecnologias e ciência. Em 2007, duas mestrandas - Debora Allebrandt (que trabalhava comigo) e Juliana Macedo (que trabalha com Daniela Knauth no Nupacs - Núcleo de Antropologia do Corpo e da Saúde) ganharam um grant da Fundação MacArthur para realizar um projeto de pesquisa muito instigante sobre novas tecnologias reprodutivas (ver Allebrandt; Macedo, 2007). Mas não sei até onde vou com isso, se vou ter ou não uma interlocução no futuro com os estudantes. A gente vai definindo os temas em função da relevância social e política, em função da demanda, da possibilidade de interlocução. Também estou comprometida com um novo projeto na Argentina - o doutorado em Antropologia Social da Universidade de San Martín. É uma realidade completamente nova para mim, uma língua nova, e com estudantes que têm outro "estilo de raciocínio"... Ao mesmo tempo, permanece uma equipe de estudantes de pós-graduação na UFRGS trabalhando sobre adoção e a circulação de crianças. Vamos ver para onde tudo isso leva a gente.

Roteiro, entrevista e edição: Ana Luiza Carvalho da Rocha e Cornelia Eckert Câmera: Rafael Victorino Devos Som: Viviane Vedana Bolsistas IC: Gutcha Ramil (transcrição), Stephanie Bexiga (apoio gravação) e Priscilla Farfan (apoio gravação)

Horizontes Antropológicos, Porto Alegre, ano 15, n. 32, p. 331-352, jul./dez. 2009 


\section{Referências}

ALLEBRANDT, D.; MACEDO, J.L. de(Org.).Fabricando a vida: implicações éticas, culturais e sociais do uso de novas tecnologias reprodutivas. Porto Alegre: Metrópole, 2007.

BARCELLOS, D. M. et al. Comunidade negra de Morro Alto: historicidade, identidade e territorialidade. Porto Alegre: Editora da UFRGS, 2004.

BOFF, A. O namoro está no ar... Na onda do outro: um olhar sobre os afetos em grupos populares. Santa Cruz do Sul: Editora da Unisc, 1998.

BRITES, J.; FONSECA, C. (Org.). Etnografias da participação. Santa Cruz do Sul: Edunisc, 2006.

CIRANDA, cirandinha: histórias de circulaçäo de crianças em grupos populares. Realização: Andrea Cardarello, Claudia Fonseca, Patrice Schuch e Rogério Rosa. Direção: Claudia Fonseca. Produção: Navisual. Porto Alegre: Laboratório de Antropologia Social, PPGAS IFCH UFRGS, 1994. 1 videocassete (25 min), NTSC SP, color.

FONSECA, C. Some considerations on the limits of anthropological theory as applied to community development. Anthropos, v. 77, n. 13, p. 363-389, 1982.

FONSECA, C. Gênero e cotidiano. Cadernos de Antropologia, n. 3, Porto Alegre, p. 1-22, 1991.

FONSECA, C. Nos caminhos da adoção. São Paulo: Cortez, 1995.

FONSECA, C. Família, fofoca e honra: a etnografia de violência e relações de gênero em grupos populares. Porto Alegre: Editora da UFRGS, 2000.

FONSECA, C. De afinidades a coalizões: uma reflexão sobre a transpolinização entre gênero e parentesco em décadas recentes da antropologia. Ilha: Revista de Antropologia, Florianopolis, v. 5, n. 2, p. 5-32, 2003.

FONSECA, C. Apresentação: de família, reprodução e parentesco: algumas considerações. Cadernos Pagu, Campinas, n. 29, p. 9-26, 2007. 
FONSECA, C.; CARDARELLO, A. Direitos dos mais e menos humanos. Horizontes Antropológicos, Porto Alegre, ano 5 n. 10, p. 83-121, 1999.

FONSECA, C.; SCHUCH, P. (Org.). Políticas de proteção à infância: um olhar antropológico. Porto Alegre: Editora da UFRGS, 2009.

FLEISCHER, S. ; SCHUCH, P.; FONSECA, C. (Org.). Antropólogos em ação: experimentos de pesquisa em direitos humanos. Porto Alegre: Editora da UFRGS, 2007.

JARDIM, D. F. Famílias palestinas no extremo Sul do Brasil e na diáspora: experiências identitárias e aduaneiras. Cadernos Pagu, Campinas, n. 29, p. 193-225, 2007.

MOTTA, F. de M. Velha é a vovozinha: identidade feminina na velhice. Santa Cruz do Sul: Edunisc, 1998.

PEIRANO, M. Uma antropologia no plural: três experiências contemporâneas. Brasília: Editora da UnB, 1992. 